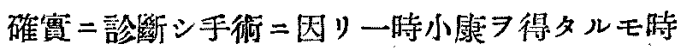
期嘅:晚ク逐二不幸ノ轉歸 アトリタルモノニシ

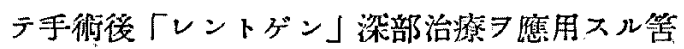
ナリシモ患者ノ都合ニテえア行フタ得ザリシ 遺澸卜ス。最後=本症，早期診断，必要 7 主張 セリ。

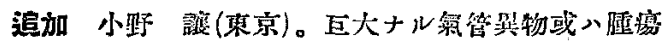

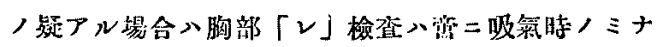

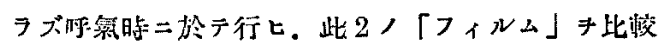

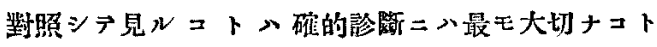

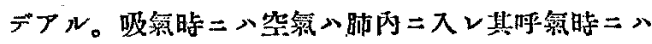

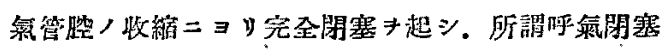

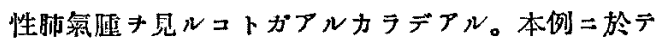
カ・ル「レ」線檢桖キナサレシャ否ヤ。

鷹答 杂田暂三郎(大阪)。「レントケ゚ン撮影法入前

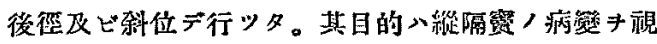

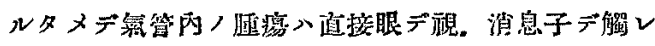
ルコトガ出來ルタメ二其必姴キ感ジナカッタ。

\section{類題 乳兒馨門下腔二發生七ル}

\section{淋巴管內皮細胞腫ノ一例}

$$
\text { 䇥 敦子(菓 京) }
$$

㢣門下腔二於ヶル内皮細胞腫, 報告八稀ニシ テ 本邦二於テ八細兄. 北野网氏ノ報告アル，

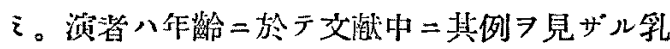
兒ノ該症例二遭遇七シ

$$
\text { 症例 }
$$

舁者 生後4万月八發育良好ナル女兒。

主訴呼吸困蜼。初喰昭和 10 年 9 月 13 日。 家族症及ビ既往症 特記スベキモノナシ。

現病歷 生後1 ケ月目ヨリ時タ「箱ノ中二テ 榢スル如キ」特異ナル要嗽アリ。約 20 日前ヨ リ夜間發作性呼吸困難 7 兆タシ次第二壖强。遂

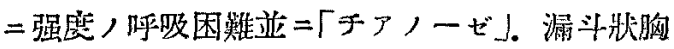

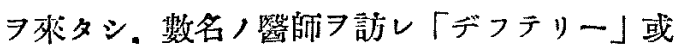

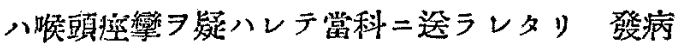

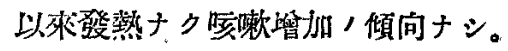
現掟 骷溫 $37.2^{\circ} \mathrm{C}$ 。脈搏 190 . 整。緊張良。 呼吸數 64. 强度 /呼吸因難アリテロ愿及ビ四肢 沫端「チアノーゼ」フ呈ス。颛鳴著明ナルモ胸 腹部䁍器二著變ナシ。血液像. 尿所見異狀ナク。

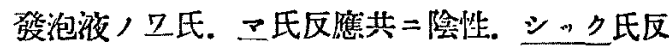
應. アント二氏反應，母乳，荒川氏反應等新レ モ狯性。

局所所見 耳. 鼻. 咽頭=涊ムべキ所見ナク. 咽頭分泌物中二「デフテリー」菌陰性。馨音清 澄ナリ。喉頭直遵鏡檢查八呼吸困難强度ナル篇 メ行フヨ得ズ. 取り敢ズ下氣管玚開

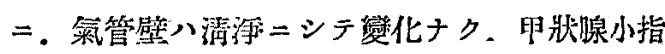

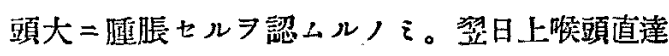
鏡检查 7 施行. 所見. 兩側馨帶正常. 丽側假馨 需二轅度, 發赤腫脹アリ。䠛門下腔粘膜珠=右 側二發赤喠脹著明ナリ。㼁膜. 異物等ハ之ヨ認 $x ス ゙$.

經過及ビ治潦 術後分泌物多量. $38^{\circ} \mathrm{C}$ 内外 ノ發熱つリ。16日目ヨリ「ネオサルヴルサン」 注射 7 母子共二始メシモ笑效ナキヨ以テ 3 回さ テ止ム。40日目直達鏡所見。喉頭粘膜/炎症症 狀ナク. 擎門下腔右後壁二表面平滑. 大豆大. 半球狀二限局七ル腫脹物アリ。腫瘍ノ疑 X線寫真撮影フナ七ルニ喉頭下部二於テ氣道

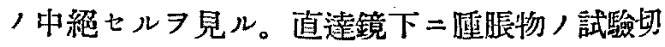

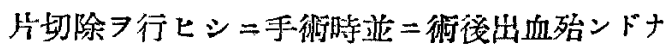
シ。病理組䋐學的診斷八 LJmphangioendotheliom ナリショ以テ，再ビ直達鏡下二可及的婳 演习鋪除セり。後療法トシテ㘈頭外部ヨリ「ラ ヂウム」照射フ行フ。照射後 50 日目頃ヨリ呼 吸困難䌊解シ照射量 $700 \mathrm{mg}$ 時二及ビシ現在所

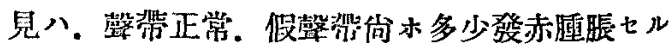




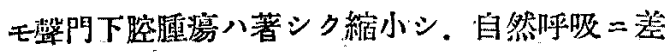

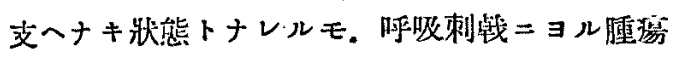
堵大ヨ恐レテ佾ホ氣管套管ヨ拔去セズ經過霍察 中ナリ。

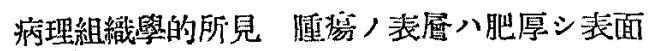
不平ナル圆柱彇、䯚子型及ビ多型重展上皮 $=$ テ 㠅ハレ，其內部八搌張セル淋巴管多數アリテ其 間質八鬆粗ナル結䋨織ヨリ成儿。又多數ノ撗㖘 七ル血管膑アリテ Cavernom，如ク排列セル 所フリ。此增生セル淋巴管八䇣狀二增殖シテ淋 巴管內占細胞㹸 7 形成ス。明 $=$ 内腔 7 認メラル ル部分アルモ。或部二於テハ內皮細胞內腔二管 生シテ其崩壞ニヨリ不規則ナル裂隙狀ノ腔 スル部アリ。

\section{考案}

幼小兒二呼吸困難 來タ テッ一」. 擎門下喉頭炎特 $=$ 先天徨素 $=ヨ ル モ$

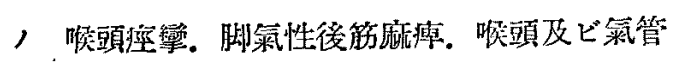

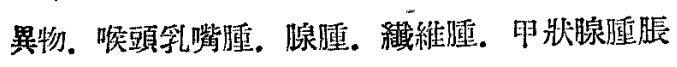

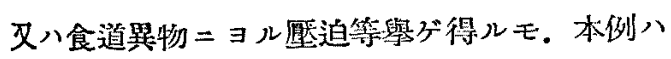
生後 1 ケ月テテ發病シ。經過比較的䜌慢ナル照。

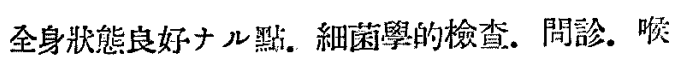
頭内所見等 7 綜合シテ大本ハ除外シ得タリ，只

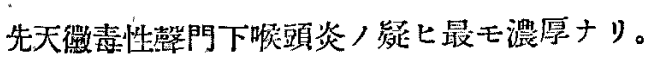
Z氏. 卫氏反應八舁兒及ビ兩親卜共二陰性ナリ シモ. 份木驅徽療法/奏效 7 期待シ母子共 $=己$ ア行ヒシモ效ナシ。幼兒二多キ乳嘴腫ト八其外

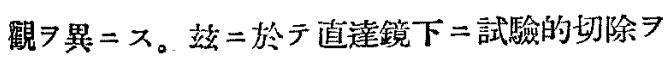
行七. 病理組織學的检查 $=ヨ$ リ初メテ铨断シ得 タルモノナリ。喉頭二於ケル内皮細胞腫，報告 例八偨少ニシテ，殊二檠門下腔二於ケルハ我國 二於テ大正 6 年細見氏，17歳女子二於少。. 昭和 6 年北見氏，37 歳男子二於ケル2例 7 見
ルノミナリ。年噒ハ一般二中年以上トサレ Carnevale-Ricci 氏，14 歲最低ニデ.本例/如 ク幼少ナルモノ=ハ其例

結势椧

本拝例八生後 4 ケ月女兒二於テ見タル馨門 下腔淋巴管內度細胞䭪ニシテ. 恐ラク先天的二

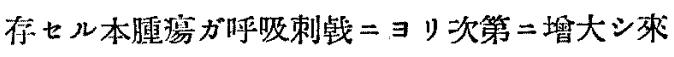

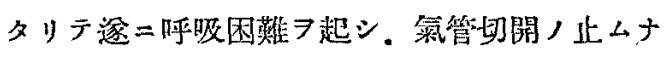

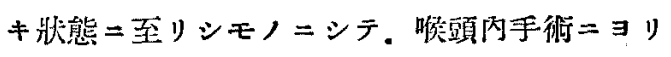

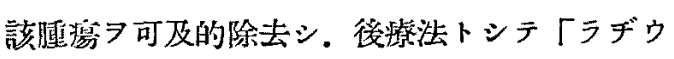
ム」照射习行ヒ。んニヨリテ殘存セル隀瘍著シ ク緶小シ。砝ンド自然呼吸管ミ得ル二至ル迄 治慮ニ赴キシモノナリ。

\section{0. 弹管枝異物/死因的救急法}

山川强四郎(阪大)

秒了大ナル球形氮管枝異物 7 全身磨睟ノ下= 除去七ントスル際又八其直達檢香操作中二於テ 急激二死亡スル事フリ。此死因二關シ先年長崎 二於ケル總會二於于余八宣例二依り「異物が喉

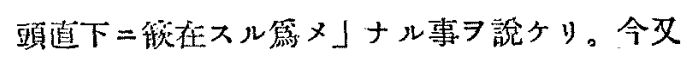
1 年 8 ケ月，女兒二於テ。氣管枝異物落花生 7 除去セントシラ「クロ、ホルム」.「エーテル」

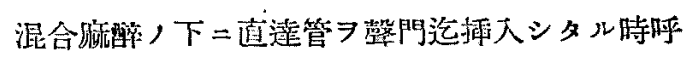

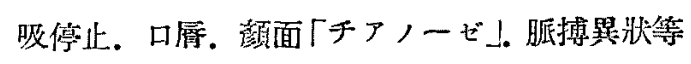
フ來タシ剂タ死二近ッ゙クラ゙認メタリ。此變化， 原因八異物ガ喉頭直下二在り。全身麻醉中，故 フ以テ再吸引スル事能ハザル二依ル事ヨ確 $\times 以$ テ前說フ確ムルラ得タリ。份ホ且ツ教室員种由 君ガ犬二於テ行ヘル成績=依レバ，2 日間，屒 キニ亘リ「ゴム」ヨ以ラ一側氣管枝习閉塞シ後 えヨ去りテ健側莱管枝 7 閏塞スルモ死スル迄 20 分間ノ俆裕アリ。之ョリ短時日一側 フ閉塞シ タ場合そタ去りテ他側 7 閉塞スル時ハー層長時 